\title{
Students' Entrepreneurial Intelligence Development Through Program Mahasiswa Wirausaha(PMW) at Universitas Pendidikan Indonesia
}

\author{
Syaifullah Syaifullah ${ }^{1}$, Dwi Iman Muthaqin ${ }^{2}$, Nisrina Nurul Insani ${ }^{3}$, Pitria \\ Sopianingsih ${ }^{4, *}$, Elda Dwi Pratiwi ${ }^{5}$
}

\author{
1,2,3,4,5 Universitas Pendidikan Indonesia, Bandung, Indonesia \\ ${ }^{*}$ Corresponding author.Email: pitrias@upi.edu
}

\begin{abstract}
Currently, the number of unemployed young people, including university graduates, is still very high. To reduce the number of unemployed, the government launched the National Entrepreneurship Movement (GKN) with the hope that the new workforce will no longer rely on the availability of existing jobs but can create their own jobs according to their competencies. Through the Entrepreneurial Student Program (PMW) it is hoped that students can become entrepreneurs who are ready to compete in today's business competition. For this reason, a program is needed that can encourage student activity and creativity as citizens with an entrepreneurial spirit so as to give birth to new entrepreneurs among students. This research was carried out using a qualitative and quantitative approach with a Research and Development ( R \& D) design. With this R \& D design, it is hoped that a new product will be produced on the development model Interpersonal Skill through the Entrepreneurial Student Program at the Indonesian Education University. The research location is on the UPI Campus, with the research subject being UPI students who take part in PMW activities in 2020 2021. With the financial assistance from the Indonesian Education University, it encourages students to be able to practice creative and innovative thinking skills in developing businesses and generating benefits for themselves and those around them so that they can build citizen engagement (civic engagement) in nation building.
\end{abstract}

Keywords: Students, Entrepreneurship, Civic Engagement.

\section{INTRODUCTION}

One of the goals of the Indonesian state as stated in the fourth paragraph of the preamble to the 1945 Constitution of the Republic of Indonesia is to realize the welfare of the people. In reality, this nation's goals are still being continuously fought for, because the welfare index to be achieved is still very far from what the aspired to founding fathers. Indonesia is still faced with the problem of high unemployment which results in low productivity and welfare. The unemployment rate in Indonesia is increasing during the Covid-19 pandemic. From the data on the number of workers who were laid off from the formal and informal sectors, the number of workers who were laid off and laid off has increased, causing the unemployment rate to soar. [1]

The Central Statistics Agency (BPS) recorded that the number of open unemployment in Indonesia reached $8,746,008$ people in February 2021. The number increased by $26.3 \%$ compared to the same period last year. The increase in unemployment is due to the economic crisis caused by the pandemic Covid-19. The majority of Indonesia's openly unemployed are high school graduates (SLTA) or general high schools (SMU) with a total of 2,305,093 people unemployed until February 2021. Meanwhile, Vocational High School or Vocational High School (SMK) followed with a total of $2,089,137$ people. unemployed. Then in third place is the number of unemployed graduates of Junior High School (SLTP) as many as 1,515,089 people. The smallest number of unemployed comes from those who do not or have never attended school. The group contributed 20,461 people [2].

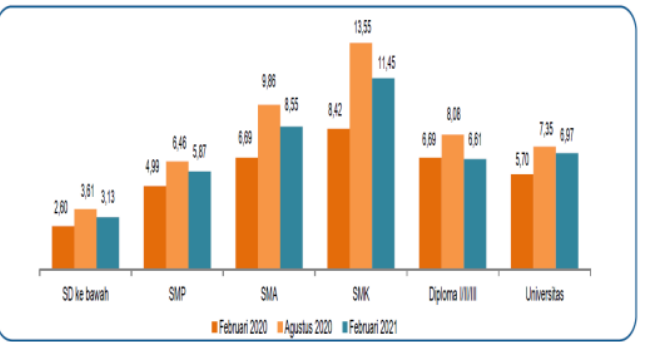

Figure 1. Unemployment Rate by Education Source: BPS, 2021 
As it is understood that if a country wants to progress, then the number of entrepreneurs (entrepreneur) is at least $2 \%$ of the total population. Thus, if Indonesia has a population of 240 million, it must have a minimum of $4,800,000$ people. However, based on BPS data in 2020 there are $3,707,205$ entrepreneurs or $1.54 \%$ of the total population of Indonesia. This means that to meet the minimum number of entrepreneurs, 1,092,795 people still have to be fulfilled. To reduce the number of unemployed, the government launched the Gerakan Kewirausahaan Nasional (GKN) with the hope that the new workforce will no longer rely on the availability of existing job opportunities but can create their own jobs according to their competencies.

One of the breakthroughs to increase the entrepreneurial spirit among students and to stimulate college graduates to become entrepreneurs is the Entrepreneurial Student Program (PMW) from the Directorate General of Higher Education, Ministry of Education and Culture. Policy The Student Entrepreneurial Program (PMW)was launched by the Government in 2009 through the Ministry of National Education. The existence of this program is supported by the fact that most university graduates start entrepreneurship on the basis of science, technology and art that they are studying so that this program is intended to facilitate students who have entrepreneurial interests and talents to be more stimulated to become job creators than job seekers. With this program, it is expected to be able to support the government's vision and mission in realizing the independence of the nation through job creation so that it can empower jobs that can reduce the number of educated unemployment in Indonesia and revive the Indonesian economy.[3]

To support the success of the Program Mahasiswa Wirausaha (PMW) Universitas Pendidikan Indonesia also encourages students who have an entrepreneurial spirit to participate in the program. Currently, the number of UPI students for the 2010/2021 academic year is approximately 40,000 people. Of course, this amount is quite large in quantity and becomes a valuable capital in preparing the younger generation for nation building. To give birth to students as entrepreneurs who are ready to compete in today's business, it is necessary to have programs that encourage students' activities and creativity as entrepreneurial spirits, such as being willing and able to seize business opportunities, seeking and utilizing capital for business. With the entrepreneurial spirit possessed by students, it will be able to reduce the unemployment rate after the student completes his studies. This study tries to examine the potential empowerment of students through entrepreneurship programs towards the independence of society and the nation. The researcher believes that this problem needs to be studied as an effort to formulate ideas about the implementation of civic engagement which plays an important role in empowering students through the Program Mahasiswa Wirausaha (PMW).

\section{THEORETICAL REVIEW}

\subsection{Entrepreneurial Intelligence}

Intelligence entrepreneur or entrepreneurial intelligence is spirit and the ability to create added value from the implementation of creativity and personal strengths into a sustainable and profitable business venture, "that impulse and ability to harness and power creativity's his personality into a business or business that can provide added value for himself.[4]

There are several skills that must be possessed by an entrepreneurial student including: 1) Having conceptual skills in setting strategies and calculating risks; 2) Have leadership and management skills; 3) Have technical skills in the field of business; 4) Have communication and interaction skills, and 5) Have creative skills to create added value.

\subsection{Empowerment Substance}

According to Stewart (1994) empowerment is defined as a quality of the internal power of an individual's personality or organization in realizing and adapting to the environment [5]. The orientation of empowerment includes excellence, progress, sustainability. Referring to that understanding, youth empowerment is interpreted as the quality of the internal personality of the younger generation in actualizing themselves, as well as the ability to adapt to their environment. Based on this formula, two important indicators of youth empowerment can be found, namely:

1. Self-actualization of all the potential or abilities it has.

2. The ability to make adjustments to the environment, both the social environment and the natural physical environment.

With the two capabilities above, the embodiment of the quality of the youth's internal power can be optimally improved in accordance with all the potentials of the younger generation.

\section{METHODS}

This research was conducted using a qualitative and quantitative approach with a Research and Development (R \& D) design. According to Creswell (2009, p. 295) a qualitative approach is a research process and description based on a methodology to investigate a social phenomenon and community problems.[6] Meanwhile, Sugiyono reveals that quantitative research is a research procedure based on the philosophy of positivism, used to study populations or certain illustrations, collecting information using research instruments, analyzing statistical information with the aim of testing established hypotheses.[7] With this R \& D design, it is hoped that a new product will be produced on the development model Interpersonal Skill through the Entrepreneurial Student Program at the University of Education Indonesia. The research location is on the UPI Campus, with the research 
subject being UPI students who take part in PMW activities in 2020-2021.

\section{RESULTS AND DISCUSSION}

Implementation of the Universitas Pendidikan Indonesia Student Entrepreneurship Program has been adjusted to the provisions of the Indonesian Student Business Competition Guidelines published by the National Achievement Center - Ministry of Education and Culture, so that the implementation of this program is in line with the goals of the central government. The main objectives of implementing the Indonesian Entrepreneurial Student Program are (1) integrating hard and soft skills (skills knowledge, skills, personal qualities: motivation, attitude, behavior, traits, values) so as to form entrepreneurial capacity, (2) encouraging the growth of young, science-based entrepreneurs, (3) encourage the establishment and strengthening of entrepreneurship development institutions at the Universitas Pendidikan Indonesia.

Universitas Pendidikan Indonesia tries to initiate and build sustainable entrepreneurship development with a planned, systematic and progressive management system and synergize with the national entrepreneurship development program. Therefore, it is expected that students who take part in this program can produce outputs in the form of: (1) (Student Entrepreneurial Gallery Documentation) the development of the character and spirit of science-based entrepreneurship (at least $1 \%$ of the number of active college students), (2) Increasing the quantity and quality entrepreneurial students at the Indonesian Education University, and (3) Increasing student entrepreneurship units that have been successfully developed at the Indonesian Education University. The technical implementation of the Entrepreneurial Student Program at the University of Indonesia Education is carried out in various stages as follows: 1) Socialization of PMW at the faculty and regional campus levels; 2) Registration and submission of PMW proposals; 3) Administration selection both offline and online; 4) Business education and training; 5) Determination and granting of business capital; 6) Monitoring and evaluation.

Students who join this program are students selected from various selection assessments, who will then be provided with education and business training. In addition, students will also be given business capital and their business activities will be monitored by the university. So that the funds that have been spent can be accounted for while achieving the expected results, namely building entrepreneurial capacity and entrepreneurship development at the Indonesian Education University. Students who successfully pass to carry out the Entrepreneurial Student Program are students who have met several predetermined criteria and requirements. The criteria and requirements that must be met include: a. Participants of the Entrepreneurial Student Program are students of the University of Education of Indonesia who are active and registered to take part in the undergraduate education program (S-1) a maximum of semester VII or Diploma level maximum of semester V;

b. Participants of the Entrepreneurial Student Program are students who have never or are not currently receiving capital funds or grant funds.

c. Entrepreneurial Student Program is attended by groups and not individuals;

d. The members of the proposing group are 4-6 people;

e. The names of the proposers (chairman and members) must be written in full and should not be abbreviated;

f. Proposing students come from the same study program or across study programs;

g. Membership of each group of Entrepreneurial Student Program can come from two different batches or the same batch.

In addition, the business criteria submitted by students must meet several conditions, namely: (1) The business being run is not a branch, not a franchise business and/or not a business in the form of Multilevel Marketing (MLM) from a company owned by another person/party. (2) The type of business should be included in the creative economy category, especially in the fields of merchandise, tourism, ICT, culinary and so on. (3) The type of business should contain uniqueness compared to products or services that have existed in the previous market. Unique does not mean completely different, but there is added value or differentiator compared to similar products or services from certain aspects such as packaging, shape, taste, color and/or production system/concept, price, management and marketing. (4) A business project can be in the form of a new business (not yet implemented), but it will be more appreciated in the form of a development from a previously self-run business. For proposers who have entrepreneurial experience and or are running a business, evidence such as photographs should be attached to the registration file and samples of their products/services to be brought during the hearing. (5) The business project must be feasible from many business aspects, including feasible to be developed with a grant of Rp. $6,000,000$, - by doing in groups.

The selection carried out by the Indonesian Education University consists of two stages of selection, namely administrative selection and proposal presentation selection. The administrative selection includes the selection of the completeness of registration documents online and offline, both biodata and student business proposal drafts. Presentation Selection includes the suitability of presentation skills and the level of feasibility of a business proposal. Students who have passed the administrative selection will then be assessed by an assessment team in their field. Study programs and faculties are responsible for the correctness of the data sent to the Directorate of Student Affairs. If data is found to be inconsistent and a violation of existing provisions, 
the Directorate of Student Affairs at the Universitas Pendidikan Indonesia has the right to cancel the proposal.

Students who successfully pass the two stages of selection above are entitled to receive financial assistance from the Indonesian Education University to develop their business. The cost components given to the participants of the Entrepreneurial Student Program are: Rp. $6,000,000,-/$ group of 4 to 6 people. The financing mechanism follows the implementation flow of the Student Entrepreneurial Program in the first phase of $70 \%$ and the second phase of $30 \%$ after monitoring the business progress report.

As long as students carry out this entrepreneurship program, the university will carry out monitoring and evaluation to ensure the quality of program implementation. The Pemonev team is appointed by the Directorate of Student Affairs with the main task of conducting monitoring and evaluation on reports and through field reviews. After conducting monev, the Pemonev Team will provide an assessment. The results of this monev assessment will be used as one part or basis in the Phase II Disbursement of Funds. Each participant of the Entrepreneurial Student Program is required to make a progress report and a final report on activities in writing and send hardcopy and softcopy of the progress report and final business report through the Student Affairs Directorate.

The implementation of the Entrepreneurial Student Program at the University of Education Indonesia has been able to develop the entrepreneurial intelligence of students at the University of Education Indonesia. Entrepreneurial intelligence is the ability to think and act creatively and innovatively to produce something that has use value or added value. With the financial assistance from the University of Indonesia Education, this encourages students to be able to practice creative and innovative thinking skills in developing businesses and generating benefits for themselves and those around them. We can measure this entrepreneurial intelligence through two main indicators, namely self-management skills (Interpersonal skills) and the ability to interact with others (Intrapersonal Skills).

One of the stages of implementing the Entrepreneurial Student Program at the University of Pendidikan Indonesia is business education and training, which aims to equip and prepare prospective entrepreneurial students. At this stage, students will meet instructors and best practices who are alumni of the tenants of the Business Incubator of the Indonesian Education University (IBUPI), and have become successful young entrepreneurs. Furthermore, the alumni of the training continued the debriefing session with mentoring and coaching which was held once a week at the UPI campus. The end result of this business education and training activity is expected to improve students' insight and performance in business which is marked by their success in producing company profiles, product profiles, and financial reports (business profiles, product profiles, and financial reports). This activity indirectly shows that students have self-management skills and the ability to interact

The results of interviews with 10 students who successfully passed the administration selection and business presentations stated that in general this training and business education provided valuable experiences that could improve their skills in self-management and interaction. One student stated that after implementing the Entrepreneurial Student Program, students were able to see a vision of the future, think to face the challenges that exist, understand passion (love for what they do and care for others). Then there were also those who stated that this program taught them how to communicate with others, managerial skills, learning to be a leader, and how to work in a team. From other interviews, it can be seen that students are also motivated to develop creativity and innovation, have strong character, are humble, have a positive attitude, and are enthusiastic to start small, dare to fail, and dare to rise again.

\section{CONCLUSION}

Implementation of the Entrepreneurial Student Program at the University of Education Indonesia has been able to develop the entrepreneurial intelligence of students at the University of Education Indonesia. We can measure this entrepreneurial intelligence through two main indicators, namely self-management skills (Interpersonal skills) and the ability to interact with others (Intrapersonal Skills). The implementation of the debriefing to improve entrepreneurship skills at the Indonesian Education University was carried out in two stages. First, the stages of business education and training with instructors and best practices who are alumni of the tenants of the Business Incubator of the Indonesian Education University (IBUPI) can empower students to start and develop their businesses. Second, a briefing session with mentoring and coaching which is held once a week at the UPI campus.

The end result of this business education and training activity is expected to improve students' insight and performance in business which is marked by their success in producing company profiles, product profiles, and financial reports. The implementation of this Entrepreneurial Student Program allows students to see a vision of the future, think to face the challenges that exist, understand passion (love of what they do and care about others), learn how to communicate with others, managerial skills, learn to be a leadership, and how to work in a team. With the financial assistance from the Indonesian Education University, it encourages students to be able to practice creative and innovative thinking skills in developing businesses and generating benefits for themselves and those around them. It is hoped that the Entrepreneurial Student Program activities can be carried out in a sustainable, structured manner and encourage young citizens to have entrepreneurial skills and social 
awareness so that they can build citizen engagement (covic engagement) in nation building.

\section{REFERENCES}

[1] V. R. Krisnandika, D. Aulia, and L. Jannah, "DAMPAK PANDEMI COVID-19 TERHADAP PENGANGGURAN DI INDONESIA," JISIP (Jurnal Ilmu Sos. dan Pendidikan), vol. 5, no. 3, 2021, doi: 10.36312/jisip.v5i3.2227.

[2] BPS, "Februari 2021: Tingkat Pengangguran Terbuka (TPT) sebesar 6,26 persen," 2021.

[3] A. Endriani and H. Hasrul, "Evaluasi Program Mahasiswa Wirausaha Tahun 2018 di Universitas Negeri Padang," J. Civ. Educ., vol. 3, no. 1, 2020, doi: $10.24036 /$ jce.v3i1.324.

[4] A. Prijosaksono and S. Bawono, The Power of Entrepreneurial Intelligence, Membangun Sikap dan Perilaku Entrepreneur Dalam Diri Anda. Jakarta: Elex Medi Komputindo.

[5] A. M. Stewart, Empowering People. London: Pustman Publishing.

[6] J. W. Creswell, Research Design (Pendekatan Kualitatif, Kuantitatif, dan Mixed). Yogyakarta: Pustaka Pelajar, 2009.

[7] Sugiyono, Metode Penelitian Kombinasi (Mix Methods). Bandung: Alfabeta, 2015. 